\title{
VALIDITY AND RELIABILITY OF POSTGRADUATE HOSPITAL EDUCATIONAL ENVIRONMENT MEASURE - BAHASA INDONESIA VERSION
}

\author{
Natalia Widiasih Raharjanti, Adhitya Sigit Ramadianto \\ Department of Psychiatry, Faculty of Medicine Universitas Indonesia
}

\section{ABSTRAK}

Latar belakang: Lingkungan pendidikan adalah faktor yang penting dalam menentukan performa akademik peserta didik program spesialis. Lingkungan yang tidak suportif dapat terkait dengan berbagai efek negatif. Postgraduate Hospital Educational Environment Measure (PHEEM) adalah sebuah kuesioner yang mengukur persepsi peserta didik terhadap lingkungan pendidikan mereka. Penelitian ini bertujuan untuk menentukan validitas dan reliabilitas dari PHEEM - versi Bahasa Indonesia.

Metode: PHEEM asli diterjemahkan dan dimodifikasi melalui diskusi panel ahli. Validitas konstruksi diukur dengan korelasi nilai item terhadap nilai total. Reliabilitas konsistensi internal diukur dengan alfa Cronbach. Sampel diambil dari residen neurologi dan radiologi.

Hasil: Pengambilan data pertama dilakukan pada 44 residen neurologi sedangkan pengambilan kedua pada 35 residen radiologi. Hampir seluruh item berkorelasi dengan nilai total, dengan $r>0,3$. Alfa Cronbach PHEEM keseluruhan adalah 0,89 dan 0,91 dari 2 kali pengambilan data.

Kesimpulan: Penelitian ini adalah yang pertama memvalidasi PHEEM di Indonesia. Beberapa perubahan dalam kuesioner dibuat untuk menjaga validitas isi. Walaupun jumlah sampel kecil dan tidak diambil secara acak, PHEEM - versi Bahasa Indonesia memiliki validitas dan reliabilitas yang layak diterima untuk digunakan dalam penelitian dan evaluasi program pendidikan dokter spesialis.

Kata kunci: lingkungan pembelajaran, PHEEM, validasi

\section{ABSTRACT}

Background: Educational environment is an essential factor influencing performance of medical residents, and unsupportive educational environment is associated with considerable harmful impacts. The Postgraduate Hospital Educational Environment Measure (PHEEM) is a self-administered questionnaire designed to measure residents' perception of their educational environment. This study aims to establish the validity and reliability of PHEEM - Bahasa Indonesia version.

Methods: The original PHEEM is translated and modified through an expert panel discussion. Construct validity is measured by corrected item-total correlation. Internal consistency reliability is measured by Cronbach's alpha. Sample was taken from neurology and radiology residents.

Results: The first validation trial was done on 44 neurology residents while the second trial was done in 35 radiology residents. Almost all item scores are correlated with the total score with $r>0,3$. Cronbach's alpha of PHEEM is 0,89 and 0,91 in the first and second trial, respectively.

Conclusion: This is the first PHEEM validation study in Indonesia; changes to the instrument were made to maintain face and content validity. While the sample size is small and not selected randomly, PHEEM - Bahasa Indonesia version has acceptable validity and reliability to be used in research and evaluation of residency programs.

Keywords: educational environment, PHEEM, validation

korespondensi: widiasih_1973@yahoo.com 


\section{INTRODUCTION}

Indonesian medical residents are assumed to have excellent academic potential, due to high level of competition in enrollment and rigorous selection process. However, observation reveals that a considerable proportion of residents faced problems during their period of study which may be caused by academic or non-academic reasons. Problem in academic performance is a result of complex interactions among many factors, including intrinsic character of the student and extrinsic influences from the educational environment. ${ }^{1}$

In broad terms, educational environment (EE) or educational climate describes what it is like to be a learner in an educational program which is influenced by the physical environment (safety, food, comfort), emotional climate (security, quality of feedback), and intellectual climate (education planning, participation, relevance). ${ }^{2}$ Supportive EE is essential for learning to take place optimally. In contrast, unsupportive EE is found to be associated with students' psychological distress. In the long run, such distress may lead to impaired academic performance and competence, burnout, deficits in professionalism, and mental health problems including suicide and substance abuse. ${ }^{1,3,4}$

Acknowledging the importance of positive EE, the World Federation for Medical Education (WFME) requires that all medical training programs evaluate the quality of their EE. The Postgraduate Hospital Educational Environment Measure (PHEEM) is an instrument developed in Dundee University to gauge students' perception of their clinical educational environment. ${ }^{5}$ A number of studies have shown the validity and reliability of PHEEM and the instrument has been subsequently adapted for use in numerous universities worldwide and diverse residency fields.

From a local perspective, Faculty of Medicine Universitas Indonesia (FKUI) and Cipto Mangunkusumo Hospital (RSCM) regularly rates pre-clinical students' perception of their educational environment using Dundee Ready Education Environment Measure (DREEM). However, no comparable survey has ever been done in any of the university's 33 residency programs. Therefore, this study aims to establish the validity and reliability of PHEEM to measure residents' perception of their educational environment and to facilitate further research in Indonesian medical education.

\section{METHOD}

PHEEM is a self-administered questionnaire using a 5-point Likert scale (scores $0-4$ ) with 40 items, divided into 3 domains: perception on role autonomy (14 items), social support (11), and teaching (15). The total score of the whole instrument, and also each of the 3 domains, can be interpreted to reflect the overall students' perception of their EE. For policymaking purposes, specific strength and weaknesses can be gathered from the score of individual items. ${ }^{5}$ The questionnaire is originally written in the English language.

The initial step of this validation study is developing a suitable translation of PHEEM in Bahasa Indonesia. The questionnaire is translated into a first draft by a certified translator from English to Indonesian. This draft is then discussed with a panel of 5 medical education experts from FKUI and changes to the draft are made if necessary. Face and content validity is also established in this phase. The draft is then back-translated into English and sent to the developer of the original questionnaire to ensure that the adjustments made in the translation process does not deviate from its intended purpose. The final product is PHEEM - Bahasa Indonesia version.

PHEEM is then tested on a sample of residents from two departments in FKUI-RSCM separately to establish validity and reliability. The two trials are planned so that adjustments can be made to improve questionnaire validity and reliability after the first trial. The residents are consecutively selected. Ethical clearance is obtained from FKUI-RSCM Research Ethics Committee.

Construct validity is measured using corrected itemtotal correlation to see whether each item possesses a strong enough correlation to the total score. The threshold is set at correlation coefficient greater than $0,3(r>0,3)$. Reliability analysis is done to measure internal consistency, expressed in Cronbach's alpha. ${ }^{6}$ The questionnaire is considered reliable if Cronbach's alpha for the whole instrument as well as its 3 domains is greater than 0,6 . Study data is managed and analyzed using SPSS version 11.5 for Windows. 


\section{RESULTS AND DISCUSSION}

\section{Translation}

The translation was conducted according to the process outlined in previous section. The expert panel discussion concluded that 4 items need to be modified to maintain face and content validity (Table 1). All modifications were discussed with and approved by one of the developers of the original PHEEM.

Table 1. Modifications on PHEEM - Bahasa Indonesia version

\begin{tabular}{|c|c|c|c|}
\hline \multicolumn{2}{|c|}{ Item Original item } & Modified item (Bahasa Indonesia) & $\begin{array}{c}\text { Back-translation of } \\
\text { modified item }\end{array}$ \\
\hline \multicolumn{4}{|c|}{ Modified in translation process } \\
\hline 1 & $\begin{array}{l}\text { I have a contract of } \\
\text { employment that provides } \\
\text { information about hours of } \\
\text { work }\end{array}$ & $\begin{array}{l}\text { Saya diberikan informasi mengenai } \\
\text { jam kerja }\end{array}$ & $\begin{array}{l}\text { I am provided } \\
\text { information about } \\
\text { hours of work }\end{array}$ \\
\hline 7 & There is racism in this post. & $\begin{array}{l}\text { Ada isu SARA (suku, agama, ras } \\
\text { dan antar golongan) di bagian ini. }\end{array}$ & $\begin{array}{l}\text { There are ethnicity, } \\
\text { religion, race, } \\
\text { and other group } \\
\text { discrimination issues } \\
\text { in this post }\end{array}$ \\
\hline 11 & I was bleeped inappropriatelly & $\begin{array}{l}\text { Saya dipanggil untuk mengerjakan } \\
\text { tugas yang bukan bagian dari } \\
\text { pendidikan }\end{array}$ & $\begin{array}{l}\text { I am asked to do tasks } \\
\text { that are not part of } \\
\text { my education }\end{array}$ \\
\hline 17 & $\begin{array}{l}\text { My hours conform to the } \\
\text { New Deal }\end{array}$ & $\begin{array}{l}\text { Jam kerja saya sesuai dengan } \\
\text { peraturan yang ada }\end{array}$ & $\begin{array}{l}\text { My hours conform to } \\
\text { current policies }\end{array}$ \\
\hline \multicolumn{4}{|c|}{ Modified after first validation trial } \\
\hline 16 & $\begin{array}{l}\text { I have good collaboration } \\
\text { with other doctors in my } \\
\text { grade }\end{array}$ & $\begin{array}{l}\text { Saya menjalin kerja sama yang baik } \\
\text { dengan dokter sejawat lain }\end{array}$ & $\begin{array}{l}\text { I have good } \\
\text { collaboration with } \\
\text { other doctors }\end{array}$ \\
\hline 20 & $\begin{array}{l}\text { This hospital has good quality } \\
\text { accommodation for junior } \\
\text { doctors, especially when on } \\
\text { call }\end{array}$ & $\begin{array}{l}\text { Rumah sakit ini menyediakan } \\
\text { akomodasi (kamar jaga) yang baik } \\
\text { untuk para dokter, terutama saat } \\
\text { jaga }\end{array}$ & $\begin{array}{l}\text {... good quality } \\
\text { accommodation } \\
\text { (on-call room) for } \\
\text { residents, ... }\end{array}$ \\
\hline 24 & $\begin{array}{l}\text { I feel physically safe within } \\
\text { the hospital environment }\end{array}$ & $\begin{array}{l}\text { Saya merasa aman secara fisik saat } \\
\text { berada di lingkungan rumah sakit } \\
\text { ini }\end{array}$ & $\begin{array}{l}\text { I feel safe physically } \\
\text { within the hospital } \\
\text { environment }\end{array}$ \\
\hline 26 & $\begin{array}{l}\text { There are adequate catering } \\
\text { facilities when I am on call }\end{array}$ & $\begin{array}{l}\text { Tersedia konsumsi (makanan dan } \\
\text { minuman) yang cukup saat jaga }\end{array}$ & $\begin{array}{l}\text { There are adequate } \\
\text { food and beverages } \\
\text { when I am on call }\end{array}$ \\
\hline
\end{tabular}


The authors and expert panel decided that 4 items of PHEEM, when translated, need to be altered to better suit local conditions. Item 1 on employment contract is not applicable to Indonesian residents, who are legally considered as university students and are not under any employment contract; thus, the phrase "contract of employment" was removed. Item 7 referring to racism was changed to reflect discrimination in Indonesian context commonly referred to as SARA (suku, agama, ras, antargolongan - ethnicity, religion, race, and other group discrimination).

Item 11 about residents being bleeped or paged is not suitable to Indonesian residents who generally stay at their stations during work hours and are not on call when outside of the hospital. The developer of PHEEM explained that item 11 asks whether residents are called to do extra work not related to their educational program; therefore, it is changed into "I am asked to do tasks that are not part of my education". Item 17 on the New Deal was modified to suit Indonesian context, where work hours are mostly decided at the discretion of the head of residency program.

After the modifications were made and approved by the original developer, the authors and expert panel concluded that PHEEM - Bahasa Indonesia version has sufficient face and content validity.

\section{Validity}

The sample for validation tests are 44 neurology residents in the first trial and 35 radiology residents in the second trial.

In the first trial, the score of all but 4 items correlate with total score with $r>0,3$ (Table 2). The weaklycorrelated items are number 16, 20, 24, 26, all of which are part of the social support domain. The 4 items were then rephrased for clarity and better suitability with the context of residency training in Indonesia. In the second trial, only item 20 still correlates weakly with the total score (Table 2). However, the $r$ value of 8 other items dropped below 0,3 .
Table 2. Corrected item-total correlation of PHEEM Bahasa Indonesia version

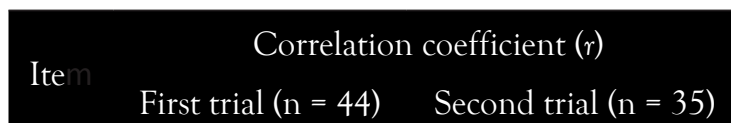

Domain: role autonomy

\begin{tabular}{|c|c|c|}
\hline 1 & 0,56 & 0,52 \\
\hline 4 & 0,62 & 0,36 \\
\hline 5 & 0,63 & 0,19 \\
\hline 8 & 0,43 & 0,35 \\
\hline 9 & 0,43 & 0,21 \\
\hline 11 & 0,46 & 0,58 \\
\hline 14 & 0,55 & 0,64 \\
\hline 17 & 0,60 & 0,57 \\
\hline 18 & 0,66 & 0,54 \\
\hline 29 & 0,70 & 0,31 \\
\hline 30 & 0,67 & 0,28 \\
\hline 32 & 0,54 & 0,52 \\
\hline 34 & 0,59 & 0,36 \\
\hline 40 & 0,55 & 0,48 \\
\hline \multicolumn{3}{|c|}{ Domain: teaching } \\
\hline 2 & 0,73 & 0,48 \\
\hline 3 & 0,46 & 0,26 \\
\hline 6 & 0,66 & 0,46 \\
\hline 10 & 0,60 & 0,16 \\
\hline 12 & 0,78 & 0,08 \\
\hline 15 & 0,77 & 0,43 \\
\hline 21 & 0,63 & 0,36 \\
\hline 22 & 0,52 & 0,34 \\
\hline 23 & 0,74 & 0,57 \\
\hline 27 & 0,48 & 0,34 \\
\hline 28 & 0,71 & 0,48 \\
\hline 31 & 0,60 & 0,35 \\
\hline 33 & 0,66 & 0,55 \\
\hline 37 & 0,74 & 0,27 \\
\hline 39 & 0,54 & 0,57 \\
\hline \multicolumn{3}{|c|}{ Domain: social support } \\
\hline 7 & 0,46 & 0,31 \\
\hline 13 & 0,45 & 0,54 \\
\hline 16 & 0,13 & 0,56 \\
\hline 19 & 0,52 & 0,48 \\
\hline 20 & 0,22 & 0,22 \\
\hline 24 & 0,26 & 0,40 \\
\hline 25 & 0,36 & 0,19 \\
\hline 26 & 0,06 & 0,47 \\
\hline 35 & 0,55 & 0,51 \\
\hline 36 & 0,24 & 0,59 \\
\hline 38 & 0,51 & 0,51 \\
\hline
\end{tabular}


The correlation between the score of each item and the total score of the whole instrument generally exceeds the threshold set at 0,3. The correlation of 3 out of 4 items with $r<0,3$ in the first trial improved in the second trial; however, $r$ value of 8 other items dropped below 0,3 . This variation may be caused by the difference in the populations from which the samples were taken, i.e. Neurology and Radiology Departments, and the lack of randomization when taking the samples.

Nevertheless, the authors and expert panel decided to keep all items in the PHEEM - Bahasa Indonesia version because those items represent essential aspects of residency program and can give actionable feedback to medical educators and residency administrators. ${ }^{5}$ A PHEEM validation study in Greece faced a similar condition and also decided not to remove any item from the instrument.

\section{Reliability}

The translated PHEEM questionnaire has a Cronbach's alpha of 0,89 in the first trial and 0,91 in the second trial. Each of the 3 domains also has Cronbach's alpha greater than 0,60 (Table 3). Hence, PHEEM-Bahasa Indonesia version can be considered reliable.

Table 3. Reliability of PHEEM - Bahasa Indonesia version

\begin{tabular}{lcc} 
& \multicolumn{2}{c}{ Cronbach's alpha value } \\
& $\begin{array}{c}\text { First trial } \\
(n=44)\end{array}$ & $\begin{array}{c}\text { Second trial } \\
(n=35)\end{array}$ \\
PHEEM (whole) & 0,89 & 0,91 \\
Domains & & \\
Role autonomy & 0,88 & 0,80 \\
Teaching & 0,92 & 0,77 \\
Social support & 0,68 & 0,77 \\
\hline
\end{tabular}

The high Cronbach's alpha of PHEEM - Bahasa Indonesia version $(0,89$ and 0,91 in the first and second trial, respectively) showed that the instrument has excellent internal consistency. The value is similar to previous studies in the United Kingdom $\left(0,91^{5}\right.$ and $\left.0,921^{7}\right)$, Greece $\left(0,933^{8}\right)$, Iran $\left(0,86^{9}\right.$ and $\left.0,94^{10}\right)$, and Sri Lanka $\left(0,84^{11}\right)$. Yet, it has also been suggested that Cronbach's alpha greater than 0,90 signals redundancy in the items. ${ }^{6}$

The value of Cronbach's alpha is influenced by at least three factors: actual reliability of the instrument, number of items in the scale, and number of response options for each item. ${ }^{12}$ However, because of the reproducibility of Cronbach's alpha for PHEEM in several studies, the authors and expert panel concluded that the Cronbach's alpha for PHEEM - Bahasa Indonesia version reflects the reliability of the instrument itself.

This study is the first in Indonesia to validate an instrument to measure the quality of educational environment at the residency level. As shown by the results of this study, the resulting instrument, PHEEM - Bahasa Indonesia version, has acceptable validity and reliability; hence, it can be used for further research in this field.

The instrument is also practical..$^{12}$ It is simple enough to be self-administered and short. Even though the authors did not record the time it took residents to complete PHEEM - Bahasa Indonesia version, our observation showed that it can be finished in less than 10 minutes without any remarkable issues.

One of the limitations of this study is the relatively small sample size with a subject-to-item ratio 0,88 and 1,1 in the first and second trial, respectively. While a survey of validation studies revealed that sample size determination is rarely justified in research papers, most studies had a subject-to-item ration equal or greater than 2. Furthermore, the sample for this validation study is not randomly selected.

Considering the modifications necessary in translating the questionnaire, the authors of this study concur with the suggestion made in another PHEEM validation study that it would be beneficial for the developer of the original PHEEM to meet with worldwide translators, validators, and users and 
discuss the future of PHEEM to ensure its lasting utility across cultural differences, in diverse settings, and through the future.

\section{CONCLUSION}

PHEEM - Bahasa Indonesia version has acceptable validity and reliability to measure the quality of educational environment in the residency level. The instrument can be used to conduct further research on educational environment and to shape educational policies in Indonesian medical residency settings.

\section{CONFLICT OF INTEREST}

The authors declare that they have no conflict of interest in this study.

\section{ACKNOWLEDGMENTS}

This study is part of the first author's Master of Medical Education thesis. The authors would like to express their gratitude to the developers of PHEEM, especially Ms. Sue Roff, without whose support this study would not have been possible. The authors would also like to thank Albert Maramis and Arisweni Adji for their translation and backtranslation of PHEEM; and Diantha Soemantri for her valuable comments on this study. The authors wish to acknowledge the contribution of the residents who participated in this study.

\section{REFERENCES}

1. Dunn LB, Iglewicz A, Moutier C. A conceptual model of medical student well-being: promoting resilience and preventing burnout. Academic Psychiatry. 2008; 32(1): 44-53.

2. Lovato C, Wall D. Programme evaluation: improving practice, influencing policy and decision-making. In: Swanwick T. Understanding medical education: evidence, theory, and practice. 2nd ed. Wiley Blackwell, 2014.

3. Dyrbye LN, Thomas MR, Shanafelt TD. Medical student distress: causes, consequences, and proposed solutions. Mayo Clin Proc. 2005; 80(12):1613-22.
4. Llera J, Durante E. Correlation between the educational environment and burn-out syndrome in residency programs at a university hospital. Arch Argent Pediatr. 2014; 112(1):6-11

5. Roff S, McAleer S, Skinner A. Development and validation of an instrument to measure the postgraduate clinical learning and teaching educational environment for hospital-based junior doctors in the UK. Medical Teacher. 2005;27(4):32631.

6. Cohen RJ, Swerdlik ME, Sturman ED. Psychological testing and assessment: an introduction to tests and measurement. 8th ed. New York: McGraw-Hill, 2013.

7. Clapham M, Wall D, Batchelor A. Educational environment in intensive care medicine - use of Postgraduate Hospital Educational Environment Measure (PHEEM). Medical Teacher. 2007; 29: 184191.

8. Koutsogiannou P, Dimoliatis IDK, Mavridis D, Bellos S, Karathanos V, Jelastopulu E. Validation of the Postgraduate Hospital Educational Environment Measure (PHEEM) in a sample of 731 Greek residents. BMC Res Notes. 2015;8:734.

9. Jalili M, Hejri SM, Ghalandari M, Moradi-Lakeh M, Mirzazadeh A, Roff S. Validating modified PHEEM questionnaire for measuring educational environment in academic emergency departments. Arch Iran Med. 2014; 17(5):372-377.

10. Shokoohi S, Emami AH, Mohammadi A, Ahmadi S, Mojtahedzadeh R. Psychometric properties of the Postgraduate Hospital Educational Environment Measure in an Iranian hospital setting. Med Educ Online. 2014; 19:24546.

11. Gooneratne IK, Munasinghe SR, Siriwardena C, Olupeliyawa AM, Karunathilake I. Assessment of psychometric properties of a modified PHEEM questionnaire. Ann Acad Med Singapore. 2008; 37:993-7.

12. Cozby PC, Bates SC. Methods in behavioral research. 12th ed. New York: McGraw-Hill Education, 2015.

13. Anthoine E, Moret L, Regnault A, Sbille V, Hardouin JB. Sample size used to validate a scale: a review of publications on newly-developed patient reported outcomes measures. Health and Quality of Life Outcomes. 2014;12:176. 